\title{
Competency-based learning: Music education, the great forgotten
}

\author{
Vernia Carrasco, Ana Mercedes
}

Department of Education and Specific Didactics, Jaume I University, Spain

\begin{abstract}
Adapting to the European framework in education, without thinking about the approaches of UNESCO, assumed that there was no type of exclusion, neither by subjects nor by profiles, however, we find a clear void regarding the competencies that a professional of music must acquire, in their training and for their employability. Not only in the strictest areas such as the Conservatories, but also in elementary schools and at the University. Our work required the help of professionals from music schools, because current laws do not refer to work in the area of competences, except in some decrees where professional competences are mentioned, or in other cases, where reference is simply made to integrate the basic skills of primary schools. The results were a proposal of basic Competences in music, which could include both conservatories and music schools, regardless of the instrumental specialty, which is a first step to establish a criterion that unifies the criteria for this group of teachers.
\end{abstract}

Keywords: Competences; Skills; Music Education; Conservatoire; Music Schools 


\section{Introduction}

Music Education in both Conservatories and Music Schools, is still adapting to the European framework for learning, so it is not surprising that public administrations in the field of education, be worried for a common framework in terms of training and education is concerned. In the European framework, basic competences, questions and options for curricular areas or subjects have been defined, as well as special classes, among which music is found, for which it is necessary to define the key or basic competences in Music that they are related to the basic competences to have a greater significance and quality in education, attending to the diversity of training and employability.

The Conservatories and Schools of Music share a common student profile to Primary and Secondary Education, and in some cases also Infantile Education, where the Basic Competences are present in all their subjects, therefore, to duplicate contents means to load the student of insignificant work at the same time you waste time and effort. The Didactic Programming in the Conservatories went from being simple bibliography, to carrying out a relevant elaboration with the LOGSE addressing the preparation of Didactic Units that covered what was established in the Curriculum. Even today we continue, too many cases, with the same programs, while in other educational levels and areas they have adapted to what has been established by Bologna.

\section{Theoretical framework}

Music education in Spain, says Longueira (2011), is developed in three areas: professional training, teacher training and music education in general training, these areas can be adapted to the competence framework:

a) the skills that professionals from specialized music education should have. These are areas that belong to professional music training and teacher training.

b) contributions of music education to the development of basic skills in general education;

c) properly musical skills that are developed in general education as part of artistic education.

Also the Music Teacher National Association (MTNA) (s/d), approved in the annual meeting of 2003 a proposal on the competences that should be acquired in Essential Skills for the promotion of a lifelong love of Music, of which we quote some:

- Ability to internalize basic rhythms and pulse

- $\quad$ Ability to read music literacy

- Possibility of performing with physical ease and technical efficiency 
- Ability to work creatively, improvise, compose, harmonize and play by ear

- Ability to understand the basic elements of the theory, the harmony form, etc.

- Ability to respond to the interpretative elements of the composition to express the emotional character of the music

- $\quad$ Ability to work independently and to solve problems

Lake and Downs (1984), long ago argued that the area of music involves creative expression, skills in rhythm, communication skills, re-establish speech patterns, recall memory, gross motor skills, sensory awareness, strengthening of the lungs .

We understand that the competition approaches or reduces the distance between theory and practice, bringing together the procedural and attitudinal conceptual contents, thus responding to traditional learning. In this sense, Bunk (1994, in Ribes, et al., 2004) believes that a competent person in the professional field is one who possesses the knowledge, skills and aptitudes necessary to develop a profession, solves problems flexibly and autonomously, and is trained to collaborate in their professional environment and in the organization of work. In the following figure, a comparison is established between the skills that Bunk defends and the competences considered by Delors:

\begin{tabular}{|c|c|}
\hline \multicolumn{1}{|c|}{ COMPETENCES (BUNK, 1994) } & LEARNING (DELORS, 1996) \\
\hline $\begin{array}{l}\text { Techniques: related to owning and } \\
\text { developing professional knowledge. }\end{array}$ & Learn to know (know) to understand. \\
\hline $\begin{array}{l}\text { Methodological: application of } \\
\text { knowledge to educational situations. }\end{array}$ & $\begin{array}{l}\text { Learning to do (knowing how to do) in } \\
\text { order to influence the environment. }\end{array}$ \\
\hline $\begin{array}{l}\text { Participatory: related to resources for } \\
\text { work in and with the group. }\end{array}$ & $\begin{array}{l}\text { Learning to live together (knowing how } \\
\text { to be) to participate and cooperate with } \\
\text { the other }\end{array}$ \\
\hline $\begin{array}{l}\text { Personals: related to human resources to } \\
\text { face professional challenges. }\end{array}$ & $\begin{array}{l}\text { Learn to be (know how to be) to live in } \\
\text { the first person. }\end{array}$ \\
\hline
\end{tabular}

Figure 1. Tipos de Competencias y aprendizajes. Source: Ribes et al. (2004).

From the previous figure we can understand that already at the end of the 20th century, there was a clear relationship between competences and learning, today we still continue with this debate in the context of music education, then, Delors' proposal is overcome or understood, we continue trying to apply the Bunk's proposal, adapting it to the specific and special field of music.

The only competition we find related to music in the educational context is the one known as Cultural and Artistic, which changes its name according to Autonomous Communities and adapts to its different decrees. But in no case does this competence refer to the acquisition of theoretical-practices content, as it does in other subjects or subjects. 


\section{Methodological framework}

To collect information, we use, on the one hand and for the proposal of competences, the exchange of information, sharing among all the participants, the proposed definitions. On the other hand, and to know the profile of the participant, we used the on-line survey, which allowed anonymously.

Our proposal went through different training courses, among whose objectives was to know the opinions of professors of Conservatories and Music Schools, so that they could discuss a first draft of basic skills in music.

Among the centers visited were 4 Professional Music Conservatories and 3 Music Schools, with teachers from different specialties participating, both in common and instrumental subjects. In addition, a course with the same characteristics was offered from the Regional Ministry of Education of the Valencian Community, addressed to all the Professional Conservatories of Music and Dance.

\section{Results}

Of all the reflections and proposals that contributed the results of the courses, finally a general list of competences was made with their respective definitions, thus leaving the following list:

- Rhythmic competence

- ditory / perceptive competence

- Vocal Competition

- Reading and Writing Comprehension Competence

- Interpretive / Communicative Competence

- Body Expression Competition (expression)

- Personal and Emotional Competence (relationship with oneself and with others, group work, etc.)

- Competence to Learn to Learn

- Technological Competence

- Cultural, Artistic (know other artistic manifestations) and Musicological competence. 
Among the reflections that we gathered from some teachers who wanted to participate, we find:

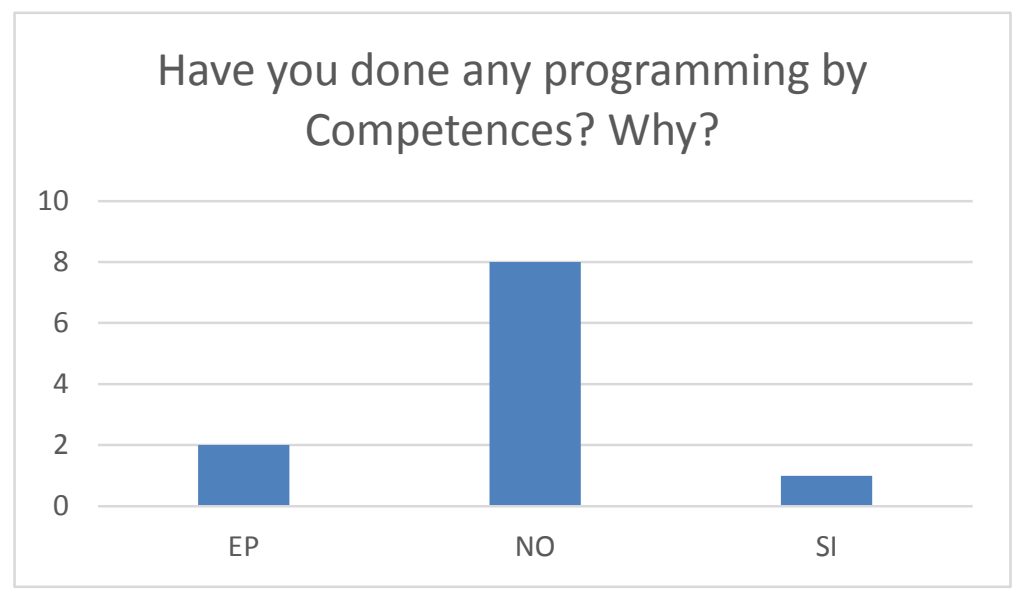

Figure 2. Have you done any programming by Competences?. Source: own elaboration

When we ask if they have ever done programming by competences, we find a majority of negative responses. The participants who did, did a programming by competences, or are in process, in most of the cases, are because from the workplace has been required.

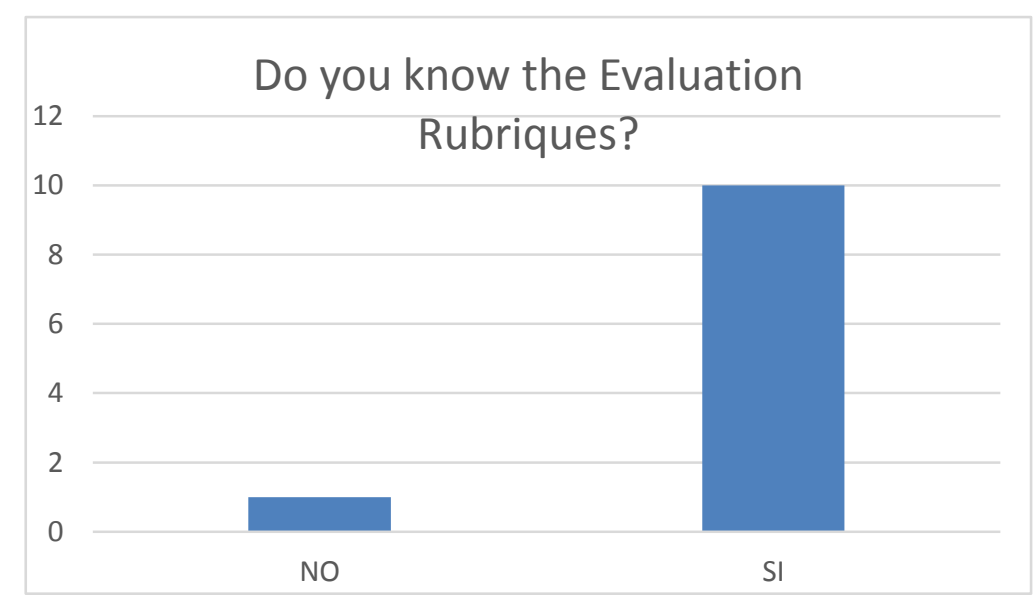

Figure 3. Do you know the Evaluation Rubriques?. Source: own elaboration 
When the participants were asked, if they knew the rubrics of evaluation, they mostly agreed, however, as we can see in the following figure, very few people use the rubrics to evaluate.

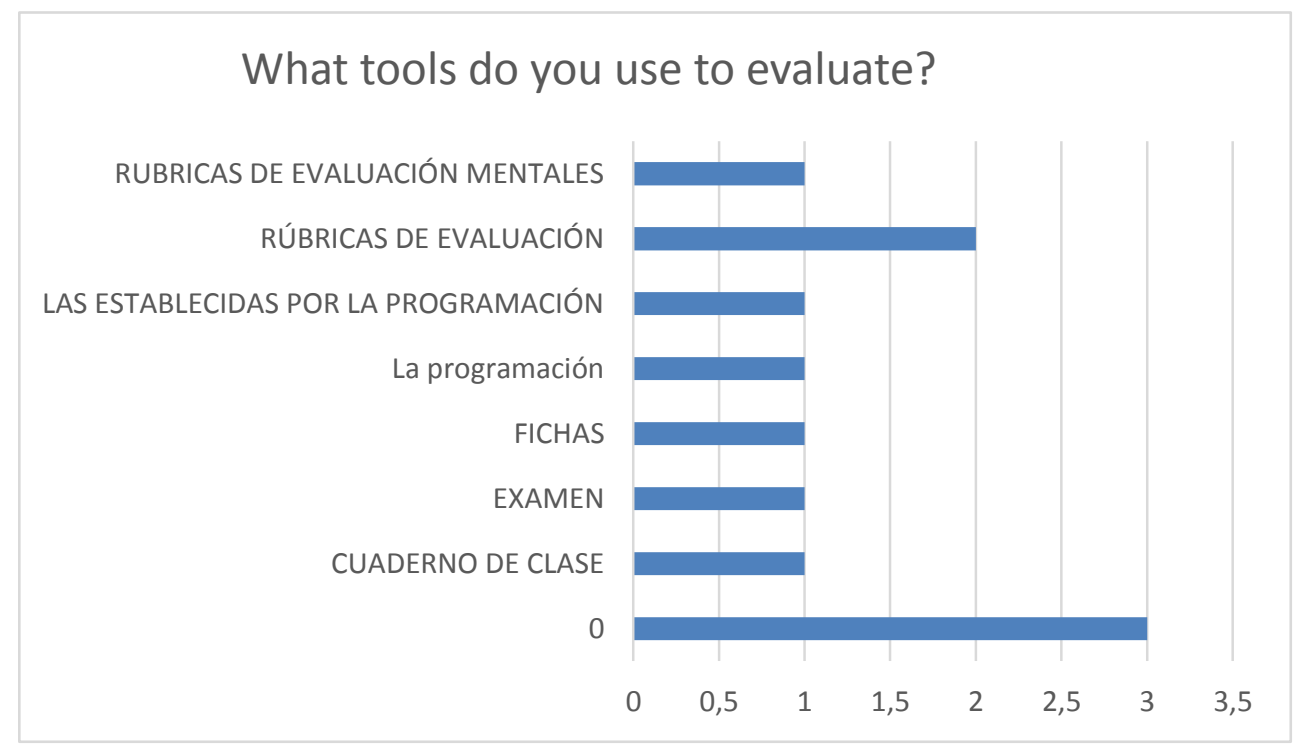

Figure 4. Tipos de Competencias y aprendizajes. Source: own elaboration

For the question: Do you see the need to improve our training in terms of programming and preparation of teaching materials? All the participants said yes

\section{Conclusions}

The first conclusion is that, with these competences, the participating teachers considered that they covered all the necessary needs and abilities that the students should assume and assimilate, when they finished their professional studies.

On the other hand, and attending to the results, we understand that it is necessary a specific training for music teachers, in terms of didactic programming by competences, according to their profile as a specialist and broadening their vision to be able to meet the European framework in educational matters. We also verified that although the rubrics of evaluation are known, there are very few teachers who apply them, some recognizing that they follow the evaluation system by traditional exam, or taking into account what their didactic program dictates. 
In addition, a training is required in this regard, both for Conservatoprios Profesionales as for Music Schools, because clearly it is that they are different from the educational areas where the key competences are already implemented, which are far, as has been appreciated, by the opinions of the specialists, of which should be applied in Education and Musical formation.

\section{References}

Lake, J. and Downs, J. (1984). Educational activity programs for older adults. A 12- month idea guide for adult education instructors an activity directors gerontology. New York. The Haworth press.

Longueira (2011) Adquisición de competencias a través de la educación musical. Aproximación al desarrollo de la responsabilidad y la autonomía en la educación general. XII Congreso Internacional de Teoría de la Educación. Barcelona: Universidad de Barcelona.

Music Teacher National Association (MTNA) (s/d). Recuperado de: https://www.mtna.org/

Ribes, R., Agulló, M.J., Corduras, J., Ribes, G.R., Marsellés, M.A., y Valls, J. (2004). “Quiero enseñar... ¿me enseñas?”. El desarrollo de competencias personales durante el período de prácticum en la formación inicial de maestro EE. Revista de Enseñanza Universitaria 24, 99-115. 